\title{
Journals of our plague years
}

\begin{abstract}
And the Waters Turned to Blood
by Rodney Barker

Simon \& Schuster: 1997. Pp. 334. \$24

Deadly Feasts: Tracking the Secrets of a Terrifying New Plague

by Richard Rhodes

Simon \& Schuster: 1997. Pp. 250. \$24, £14.99

RobertDesowitz
\end{abstract}

If Daniel Defoe were alive today, he would be known as a science writer on the strength of his A Journal of the Plague Year (1722). Richard Rhodes and Rodney Barker's books are journals of our own plague years. The authors, both of whom are journalists, differ in style, comprehensibility and calibre of writing; and their 'diseases' are very, very different. But theyboth present their accounts in a dramatic, near-novel-like fashion, each with a clearly identifiable hero or heroine (each somewhat humanly flawed), subheroes, and hissable villains in the guise of nasty scientists and even nastier government agencies heeding only special interests.

The setting of Barker's book is North Carolina, a state that cherishes the natural beauty of its shores, streams, rivers and mountains. I write this from my deck overlooking a small lake in the longleaf piney Sandhills. The trees are beginning their spring flowering spectacular and a red cockaded woodpecker is rapping away. It is hard to imagine that so pristine a place could become blighted. But in 1990, many millions of fish died in the Neuse and Pamlico rivers and their estuaries.

About the same time, fish began dying in the laboratory tanks of Edward Noga, a fish pathologist at North Carolina State University School of Veterinary Medicine. He calls on JoAnn Bukholder (the heroine), a newly appointed assistant professor of phycology at the university, for advice. Although an algae specialist, she identifies a dinoflagellate of the genus Pfiesteria as the pathogen in the rivers and Noga's tanks. This is a microorganism of fresh and brackish water previously unrecognized for its pathogenicity. So why did Pfiesteriabloom in 1990 ?

Bukholder traces the cause to an egregious violation of the environment. The state government has pandered to the politically powerful hog farmers and allowed them to dump millions of gallons of pig faeces into the rivers - to the biological delight of the dinoflagellate. She begins a crusade to halt the pollution and to cleanse the rivers. She fights for grants to continue her experimental and ecological studies. She fights the secretive Noga. She fights the chief and staff of the Division of Environmental Management. She accuses the governor of putting pigs before people. And then comes the unsettling evidence that not only are the rivers and fish sick because of the dinoflagellate, but people are too.

Bukholder develops a fever; there is a continuing lassitude and memory disturbance like that of an early Alzheimer's victim. Her assistants come down with similar neurological manifestations. They leave the laboratory and slowly recover. Fishermen of the rivers and estuaries have a similar syndrome. Bukholder now believes that the dinoflagellate is toxic to humans. The Department of Health is reluctant to accept the thesis without further proof. But that proof, from this account at least, has not been forthcoming. As with 'Gulf War syndrome', Koch's postulates remain unsatisfied.

The story ends rather inconclusively. Barker tells a good story, but descriptive science is not his strength. This is in contrast to Rhodes, who knows his way around science and scientists and whose Deadly Feasts is a scholarly, fascinating account of the transmissible spongiform encephalopathies.

Humans and their domestic animals are being killed by what appears to be a new entity. It is transmissible like a microbe but gives no signs of life, no morphological life structure, and has no obedience to life's canon of DNA to RNA to protein. It has no discernible nucleic acid and excites no immune response. All who are stricken die. The diseases are associated with amyloid fibrils that have been called prions (as well as virinos, slow viruses and amyloid rods). The latest, but undoubtedly not the last, word is that they are amyloid fibres polymerized from abnormal monomeric proteins by mutations in lysozyme (Booth et al., Nature 385, 787-793; 1997).

In the 1950s it came to the attention of the Australian colonial authorities that unusual deaths were occurring among the Fore tribe in the eastern highlands of Papua New Guinea. The natives called it kuru, the shivering death. Only the women and children died of this strange progressive neurological disease from which there was no recovery. The natives knew it as witchcraft. The Australians did not know what to make of it; no aetiological agent could be found.

Into this confused scene came, in 1957, Carelton Gajdusek, the American paediatrician, virologist, anthropologist and non-stop monologist. It was his guiding genius that solved the mystery of kuru and the related 'slow virus' diseases - notably, CreutzfeldtJakob disease and bovine spongiform encephalopathy (BSE), 'mad cow disease'.

Gajdusek and his Australian colleagues, Michael Alpers and Vincent Zigas, showed that cannibalism was the cause of kuru. The Fore women and children, but not the men, ate — totally consumed — their dead relatives.

\section{IMAGE UNAVAILABLE FOR COPYRIGHT REASONS}

A patient with kuru, the 'shivering death'.

Kuru brains were sent to Gajdusek's laboratory at the US National Institutes of Health in Bethesda, Maryland. Chimps were inoculated and after a long period they came down with the typical symptoms and died. Kuru was shown to be a transmissible disease but no infectious agent was detected.

William J. Hadlow, the American research veterinarian, brought Gajdusek's attention to the similarities between scrapie, the disease of sheep he had been studying, and kuru. The penny dropped that this is a whole new galaxy of disease. Stanley Prusiner, whom Rhodes does not like very much, bestowed the name prions on the amyloid rods, but Gajdusek won the Nobel prize.

In the last chapters, Rhodes describes the newest prion disease, BSE. He reserves his most scathing anger and contempt for the British health authorities, which refused for so long to recognize the threat when it became apparent that humans were susceptible. The animal feed industry is castigated for faulty processing of animal parts. The Swiss, Rhodes reports, were selling human placentas from abortion clinics to animal feed processors. Incredible! Rhodes serves as a kind of latter-day Sinclair Lewis, who excoriated the Chicago meat-packing industry.

The last words of Rhodes come from Gajdusek, who pronounces all amyloid diseases to be essentially the same and warns that they could bring down the human species.

This reviewer's last words are for Gajdusek, for whom this is a troubled time, to remind him that all humanity is indebted to his genius.

Robert Desowitz is in the Department of Epidemiology, School of Public Health, University of North Carolina, Chapel Hill, North Carolina 27599, USA. 